\title{
Knowledge, attitudes and practices regarding the Pap test among women in northeastern Brazil
}

\author{
Conhecimentos, atitudes e práticas sobre o exame de Papanicolaou \\ em mulheres do nordeste brasileiro
}

Carla Lorenna Ferreira de Albuquerque', Marla da Paschoa Costa', Felipe Moreira Nunes', Roberto Wagner Junior Freire de Freitas", Paulo Roberto Medeiros de Azevedo"', José Veríssimo Fernandes"v , Juciane Vaz Rego", Humberto Medeiros Barreto"

Universidade Federal do Piauí (UFPI), Campus Amílcar Ferreira Sobral, Piauí, Brazil

\begin{abstract}
'Nursing Undergraduate, Department of Health Sciences, Universidade Federal do Piauí (UFPI), Floriano, Piauí, Brazil.

"MSc. Professor, Department of Health Sciences, Universidade Federal do Piauí (UFPI), Floriano, Piauí, Brazil.

"mphD. Professor, Department of Statistics, Universidade Federal do Rio Grande do Norte (UFRN), Natal, Rio Grande do Norte, Brazil.

"vphD. Professor, Department of Parasitology and Microbiology, Universidade Federal do Rio Grande do Norte (UFRN), Natal, Rio Grande do Norte, Brazil.
\end{abstract}

\section{KEY WORDS:}

Papillomavirus infections. Uterine cervical neoplasms.

Vaginal smears.

Women's health

Socioeconomic factors.

\section{PALAVRAS-CHAVE:}

Infecções por papillomavirus.

Neoplasias do colo do útero.

Esfregaço vaginal.

Saúde da mulher

Fatores socioeconômicos.

\begin{abstract}
CONTEXT AND OBJECTIVE: The Papanicolaou (Pap) test has been shown to be effective in preventing cervical cancer. However, both the national and international literature shows that Pap testing has not reached the level of coverage desired. The objective of this study was to assess women's knowledge, attitudes and practices regarding the Pap test and to investigate whether there are any associations between these three factors and the women's sociodemographic characteristics.

DESIGN AND SETTING: Cross-sectional descriptive study conducted in Floriano, Piauí.

METHODS: The study was conducted among 493 women between November 2009 and December 2010. A questionnaire with precoded questions was used, and the responses were analyzed in terms of appropriateness in relation to the Pap test.

RESULTS: The degrees of adequacy of knowledge, attitudes and practices regarding the Pap test were $36.7 \%, 67.2 \%$ and $69.6 \%$, respectively. Among the main barriers against testing, absence of symptoms and a sense of embarrassment were the most notable.

CONCLUSIONS: Women who visit doctors periodically had the most appropriate practices regarding the Pap test, but their knowledge of the procedure was poor. This suggests that these women were not receiving adequate information about the benefits of periodic testing.
\end{abstract}

\section{RESUMO}

CONTEXTO E OBJETIVO: O exame de Papanicolaou já mostrou efetividade na prevenção de câncer do colo do útero. A literatura nacional e internacional tem mostrado que o exame de Papanicolaou não tem alcançado o índice de cobertura desejado. O objetivo deste estudo foi avaliar os conhecimentos, atitudes e práticas entre mulheres em relação ao exame de Papanicolaou e verificar se existe associação entre esses comportamentos e as características sociodemográficas.

TIPO DE ESTUDO E LOCAL: Estudo descritivo e transversal realizado em Floriano, Piauí.

MÉTODOS: O estudo foi conduzido com 493 mulheres no período de novembro de 2009 a dezembro de 2010. Utilizou-se um questionário com perguntas precodificadas, cujas respostas foram analisadas quanto à adequação dos comportamentos em relação ao exame.

RESULTADOS: Os graus de adequação dos conhecimentos, atitudes e práticas em relação ao exame foram de $36,7 \%, 67,2 \%$ e 69,6\%, respectivamente. Dentre as principais barreiras para a sua realização, destacaram-se a ausência de sintomas e a vergonha.

CONCLUSÃO: As mulheres que realizam consultas periodicamente apresentam prática mais adequada, porém com baixa adequação de conhecimentos frente ao procedimento, sugerindo que não estejam recebendo as informações adequadas sobre os benefícios da realização periódica do exame de Papanicolaou. 


\section{INTRODUCTION}

Cervical cancer is the second biggest cause of cancer-related deaths among women worldwide, but the incidence is higher in developing countries. ${ }^{1,2}$ In Brazil, this disease remains the third most common malignant neoplasm after non-melanoma skin cancer and breast cancer. ${ }^{3,4}$ In 2012, the approximate incidence rate of cervical cancer per 100,000 women was 17.49 for Brazil, 17.96 for northeastern Brazil and 22.58 for the state of Piauí. ${ }^{3}$

The etiology of cervical cancer is directly related to persistent infection of the uterine cervix with human papillomavirus (HPV) genotypes that have a high oncogenic potential. ${ }^{5,6} \mathrm{HPV}$ infection is considered to be a necessary but insufficient cause of development of neoplasms or their precursor lesions, because viral deoxyribonucleic acid is present in $99.7 \%$ of cervical cancer cases. ${ }^{7-9}$

Importantly, this malignant neoplasm is one of many cancers with great potential for prevention and cure. The progression of cervical cancer is relatively slow, passing through various stages of precancerous intraepithelial lesions before advancing to its invasive form. ${ }^{10}$ This characteristic of the disease, combined with the relative ease of diagnosis, has allowed physicians to detect this cancer during its earliest stages, when treatment results in a high cure rate. ${ }^{10,11}$ Moreover, the infectious nature of cervical cancer's etiological agent has made implementation of preventive measures possible, including active immunization against HPV genotypes with higher oncogenic potential. ${ }^{7,11,12}$

The Papanicolaou (Pap) test is a simple method for detecting morphological changes in the uterine cervix from desquamated epithelial cells. Because the test is quick, painless, broadly applicable, easy to perform, performable in outpatient clinics and inexpensive, it has been considered to be the best method for cervical cancer screening. ${ }^{10,13,14}$ However, an estimated $40 \%$ of Brazilian women have never been tested. ${ }^{15}$ Low compliance arises for many reasons, including difficulties in accessing healthcare services, emotional discomfort for some women, embarrassment, social taboos, socioeconomic conditions and poor understanding of the benefits of testing for preventing cervical cancer. ${ }^{16}$ These barriers have hindered achievement of the desired level of test coverage. Information concerning test coverage and the factors associated with test noncompliance among women in northeastern Brazil is still scarce.

\section{OBJECTIVE}

The purpose of the present study was to assess the knowledge, attitudes and practices of women in the city of Floriano, Piauí, regarding the Pap test, and to determine whether there was any association between the appropriateness of these three factors and the sociodemographic characteristics and other variables of this population.

\section{METHODS}

A cross-sectional descriptive study was conducted in the city of Floriano, Piauí, from November 2009 to December 2010, through home visits and interviews using a standardized questionnaire. The study included 493 women between 15 and 69 years of age (mean: 35.4 years) residing in both the urban and the rural areas of the municipality.

The urban center of the municipality is located $240 \mathrm{~km}$ from the state capital and the total estimated population of the municipality is 57,690 inhabitants, of whom 49,970 live in urban areas, 7,720 live in rural areas and 30,381 are female. The primary economic activities include agriculture, raising livestock, extracting natural resources and trade. Most of the population is poor and depends on the public health system, which consists of one 97-bed hospital, 25 primary healthcare units and 24 teams within the Family Health Program.

A sample size calculation was used to determine the number of women to be interviewed. This calculation used a statistical method based on the demographics of the municipality's female population and taking into consideration both rural and urban areas. The variable considered for defining the sample calculation was $p$ equals the proportion of women between 20 and 59 years of age within the population of women aged over 15 years. In this case, the calculation of sample size was given by:

$$
n=\frac{N p(1-p)}{N D+p(1-p)}
$$

where $n$ equals the sample size, $N$ equals the total number of women aged over 15 years in the city and $D$ equals $\varepsilon^{2} / 4$, such that $\varepsilon$ is a boundary error estimation of $p$, which satisfies $\mathrm{P}(|\mathrm{p}-\hat{p}|<\varepsilon)=0.95$, in which $\hat{p}$ is an estimate for $\mathrm{p}$. According to a survey conducted by the Municipal Health Department, $N=23,318$ women and a preliminary estimate for $\mathrm{p}$ was given by $\hat{p}=0.72$. By taking $\varepsilon=0.04$ and inserting these values to determine $n$ in the formula above, it was found that $\mathrm{n}=493$ women.

Three interviewers were trained to administer the survey and collect data. The research project and its objectives were explained to potential participants and assurances were given that confidential information would be safeguarded. These potential participants were then asked whether they would like to participate in the study. Those who voluntarily agreed to participate then signed an informed consent form and answered the questions on the questionnaire. The questions, which were designed to evaluate the three factors, consisted of direct questions in which the participants were asked to state their age, place of residence, education level, marital status, ethnicity, religion, family income, number of visits to a doctor during the previous year, sexual activity, use of contraceptives and parity. Only the women who voluntarily decided to participate in the study gave responses to the questionnaire and therefore there were no sample losses. The questions were asked by the interviewer orally without inducing responses.

To analyze the data we adopted the following definitions:

- Inadequate knowledge: a situation in which the women claimed that they had heard of the test but did not know the reason why the test was performed. 
- Inappropriate attitude: a situation in which the women considered testing unnecessary or had no opinion about receiving the test.

- Inadequate practice: a situation in which the women claimed to have been tested more than three years ago, to have been tested only once in their lifetime or to have never been tested.

The data collected were independently digitized twice and were stored in an Excel database. Statistical analyses were performed using the Statistical Package for the Social Sciences (SPSS) software, version 16.0. To determine whether there was any association between variables, the chi-squared test was used, and a P-value $<0.05$ was considered significant.

This research was submitted for approval to the Ethics Committee for Human Research of Universidade Federal do Piauí and was approved under the protocol number 0156.0.045.000-09.

\section{RESULTS}

Analysis of the data collected from the questionnaire allowed a profile to be created for the study participants. All of the women in the study were between 15 and 69 years of age (mean: $35.4 \pm 14.3$ years), and most were between 20 and 45 years of age. Most of the women lived in the urban areas of the municipality, possessed only elementary school education, possessed a monthly family income at or below the minimum wage level, professed Catholicism as their religion, engaged in an active sex life, were married or living in a stable relationship with their partner and had one to three children.

In terms of the degree of knowledge about the test, $94.5 \%$ of the women interviewed had heard of the procedure, but only $36.7 \%$ had adequate knowledge of the test. The doctor was cited as the primary source of information about the test by $44.2 \%$ of the participants, while friends or relatives were cited by $19.5 \%$ of the participants (Table 1 ).

Table 1. Sources of information and adequacy of knowledge relating to the Pap test in the municipality of Floriano, Piauí, Brazil, $2010(n=493)$

\begin{tabular}{lcc} 
Variable & $\mathbf{n}$ & $\%$ \\
\hline $\begin{array}{l}\text { Aware of the test } \\
\text { Yes }\end{array}$ & 466 & 94.5 \\
$\quad$ No & 27 & 5.5 \\
Purpose of the test & 74 & 15.0 \\
$\quad$ To prevent cancer & 107 & 21.7 \\
$\quad$ To prevent cervical cancer & 312 & 63.3 \\
$\quad$ Other answers & & \\
Knowledge of the test & 181 & 36.7 \\
$\quad$ Adequate & 312 & 63.3 \\
$\quad$ Inadequate & & \\
Who had given information on the test & 218 & 44.2 \\
$\quad$ Medical doctor & 96 & 19.5 \\
Friend or family & 44 & 8.9 \\
School & 41 & 8.3 \\
Radio/TV & 34 & 6.9 \\
Healthcare unit staff & 33 & 6.6 \\
Community health workers & &
\end{tabular}

All of the women interviewed considered the test necessary, but only $67.1 \%$ had an appropriate attitude regarding the procedure, through expressing conscious recognition of its advantages and benefits and correctly indicating the reasons for periodically undergoing the test. Among those who had an appropriate attitude, 46.7\% justified the need for the test as a means of preventing cervical cancer, and $20.5 \%$ justified the test as a means of preventing cancer but without specifying the type of cancer prevented (Table 2).

With regard to whether the participants had ever undergone the test, $75.9 \%$ of them reported undergoing the procedure at some point, while $24.1 \%$ reported never having undergone the test. Among those who said that they had undergone the procedure, $69.6 \%$ said that they had been tested at a frequency of at least once every three years, thus demonstrating an appropriate level of test practice, considering that this frequency is within the acceptable limits recommended by the Brazilian Ministry of Health. The primary barriers against adequate frequency of testing were reported to be absence of symptoms (39.5\%) and being too embarrassed (26.9\%) to undergo the procedure (Table 3 ).

Table 2. Attitudes towards and reasons for undergoing the Pap test reported by women in the municipality of Floriano, Piauí, Brazil, 2010 $(n=493)$

\begin{tabular}{lrr} 
Variable & $\mathbf{n}$ & $\%$ \\
The need for testing & & \\
$\quad$ Necessary & 493 & 100.0 \\
$\quad$ Unnecessary & 0 & 0.0 \\
Attitude & 331 & 67.1 \\
$\quad$ Appropriate & 162 & 32.9 \\
$\quad$ nnappropriate & & \\
Reason for testing & 113 & 22.9 \\
$\quad$ To prevent sexually transmitted diseases & 101 & 20.5 \\
$\quad$ To prevent cancer & 230 & 46.7 \\
To prevent uterine cervical cancer & 49 & 9.9 \\
$\quad$ No answer & & \\
\hline
\end{tabular}

Table 3. Test practices, adequacy of test practices and barriers against Pap testing reported by women in the municipality of Floriano, Piauí, Brazil, $2010(n=493)$

\begin{tabular}{lcc} 
Variable & $\mathbf{n}$ & $\%$ \\
$\begin{array}{l}\text { Type of test practice } \\
\text { Had been tested at some time in the past }\end{array}$ & 374 & 75.9 \\
Had never been tested & 119 & 24.1 \\
Frequency of testing & & \\
$\quad$ Had been tested at least once every three years & 343 & 69.6 \\
Had been tested at intervals greater than three years & 31 & 6.3 \\
Had never been tested & 119 & 24.1 \\
Test practice & & \\
Adequate & 343 & 69.6 \\
Inadequate & 150 & 30.4 \\
Barriers against test practice & & \\
No symptoms & 47 & 39.5 \\
Feelings of embarrassment & 32 & 26.9 \\
Fear of pain & 5 & 4.2 \\
Inability to schedule the test & 10 & 8.4 \\
Long distance to healthcare unit & 10 & 8.4 \\
Lack of time & 3 & 2.5 \\
Inability to miss work & 1 & 0.8 \\
Other reasons & 11 & 9.2 \\
\hline
\end{tabular}


Statistically significant associations between knowledge of the test and age, social class, education level and family income level were observed (Table 4). The appropriateness of the women's attitude towards the test was associated with age, schooling level, marital status, sexual activity, frequency of consultations with doctors and parity. The adequacy of test practice presented associations with age, sexual activity, numbers of consultations with doctors, contraception and parity.

\section{DISCUSSION}

Among the 493 women included in our study, most were between 20 and 45 years of age, nonwhite, Catholic, less formally educated, limited to lower family incomes, sexually active, multiparous and married or living in a stable relationship with a partner. This profile is easily explained given that these women lived in the northeastern region of the country, a region historically associated with high levels of social inequality and poverty. It is not uncommon, therefore, even in the twenty-first century, to find young women with very little formal education and no training who are housewives with children.

Our results showed that $75.9 \%$ of the participants claimed to have had a Pap test at least once in their lifetime, a rate lower than that reported for women in the cities of São Paulo $(86.0 \%)^{17}$ and

Table 4. Assessment of adequacy of knowledge, attitudes and practices relating to the Pap test, according to sociodemographic and reproductive characteristics, among women in the municipality of Floriano, Piauí, Brazil, $2010(n=493)$

\begin{tabular}{|c|c|c|c|c|c|c|c|c|c|c|}
\hline \multirow{2}{*}{ Variable } & \multirow{2}{*}{ Total } & \multicolumn{3}{|c|}{ Adequate knowledge } & \multicolumn{3}{|c|}{ Appropriate attitudes } & \multicolumn{3}{|c|}{ Adequate test practices } \\
\hline & & n & $\%$ & $\mathbf{P}$ & $n$ & $\%$ & $\mathbf{P}$ & n & $\%$ & $\mathbf{P}$ \\
\hline \multicolumn{11}{|l|}{ Age (years) } \\
\hline$<20$ & 64 & 11 & 17.2 & \multirow{3}{*}{0.001} & 24 & 37.5 & & 17 & 26.6 & \multirow{3}{*}{0.000} \\
\hline $20-45$ & 303 & 115 & 37.9 & & 212 & 70.0 & 0.000 & 229 & 75.7 & \\
\hline$>45$ & 126 & 55 & 43.7 & & 95 & 75.4 & & 97 & 77.0 & \\
\hline \multicolumn{11}{|l|}{ Stratum } \\
\hline Rural area & 46 & 13 & 28.3 & \multirow{3}{*}{0.037} & 26 & 56.5 & & 29 & 63.0 & \multirow{3}{*}{0.601} \\
\hline Lower class & 330 & 114 & 34.5 & & 219 & 66.4 & 0.101 & 229 & 69.4 & \\
\hline Middle class & 117 & 54 & 46.5 & & 86 & 73.5 & & 85 & 72.6 & \\
\hline \multicolumn{11}{|l|}{ Schooling } \\
\hline Incomplete elementary school & 180 & 56 & 31.1 & \multirow{4}{*}{0.009} & 119 & 66.1 & \multirow{4}{*}{0.014} & 124 & 68.9 & \multirow{4}{*}{0.233} \\
\hline Complete elementary school & 173 & 58 & 33.5 & & 105 & 60.7 & & 113 & 65.3 & \\
\hline Complete middle school & 115 & 53 & 46.1 & & 85 & 73.9 & & 86 & 74.8 & \\
\hline High school/college & 25 & 14 & 56.0 & & 22 & 88.0 & & 20 & 80.0 & \\
\hline \multicolumn{11}{|l|}{ Marital status } \\
\hline Single & 170 & 43 & 25.3 & \multirow{3}{*}{0.001} & 90 & 52.9 & & 79 & 46.5 & \multirow{3}{*}{0.000} \\
\hline Married & 269 & 114 & 42.4 & & 200 & 74.3 & 0.000 & 217 & 80.7 & \\
\hline Others & 54 & 24 & 44.4 & & 41 & 75.9 & & 47 & 87.0 & \\
\hline \multicolumn{11}{|l|}{ Race } \\
\hline White & 94 & 44 & 46.8 & \multirow{2}{*}{0.024} & 65 & 69.1 & \multirow{2}{*}{0.645} & 65 & 69.1 & \multirow{2}{*}{0.764} \\
\hline Nonwhite & 399 & 137 & 34.3 & & 266 & 66.6 & & 278 & 69.7 & \\
\hline \multicolumn{11}{|c|}{ Family income (monthly minimum wage) } \\
\hline Up to 1 & 349 & 115 & 32.9 & & 228 & 65.3 & & 233 & 66.8 & \\
\hline 2 to 4 & 126 & 56 & 44.4 & 0.017 & 90 & 71.4 & 0.411 & 95 & 75.4 & 0.085 \\
\hline$\geq 5$ & 18 & 10 & 55.5 & & 13 & 72.2 & & 15 & 83.3 & \\
\hline Visits to a doctor during precedin & & & & & & & & & & \\
\hline No & 198 & 56 & 28.3 & 0.002 & 121 & 61.1 & 0.019 & 92 & 46.5 & 0.000 \\
\hline Yes & 295 & 125 & 42.4 & 0.002 & 210 & 71.2 & 0.019 & 251 & 85.1 & 0.000 \\
\hline Sexually active & & & & & & & & & & \\
\hline No & 58 & 13 & 22.4 & 616 0 & 26 & 44.8 & חمחת & 11 & 19.0 & חمחم \\
\hline Yes & 435 & 168 & 38.6 & 0.010 & 305 & 70.1 & 0.000 & 332 & 76.3 & 0.000 \\
\hline Contraception use & & & & & & & & & & \\
\hline No & 257 & 88 & 34.2 & 0235 & 164 & 63.8 & 101 & 162 & 63.0 & 10०ח \\
\hline Yes & 236 & 93 & 39.4 & 0.235 & 167 & 70.8 & 0.101 & 181 & 76.7 & 0.001 \\
\hline Parity & & & & & & & & & & \\
\hline None & 115 & 26 & 22.6 & & 60 & 52.1 & & 51 & 44.3 & \\
\hline 1 to 3 & 260 & 111 & 42.7 & 0.002 & 185 & 71.2 & 0.001 & 207 & 79.6 & 0.000 \\
\hline 4 to 6 & 77 & 31 & 40.2 & 0.002 & 58 & 75.3 & 0.001 & 53 & 68.8 & 0.000 \\
\hline 7 or more & 41 & 13 & 31.7 & & 28 & 68.3 & & 32 & 78.0 & \\
\hline Total & 493 & 181 & 36.7 & & 331 & 67.1 & & 343 & 69.6 & \\
\hline
\end{tabular}


São Luís do Maranhão $(82.4 \%)^{18}$ and in the municipality of São José de Mipibu, in the state of Rio Grande do Norte (85.0\%). ${ }^{19}$ A significant proportion of the study participants (24.5\%) admitted to never having had the test. Our rate was higher than the rates observed in the three studies mentioned above, where the percentages of women who had never undergone the test were $13.9 \%, 17.6 \%$ and $15.0 \%$, respectively. A similarly low rate of $11.2 \%$ was reported in Campinas, state of São Paulo. ${ }^{16}$

However, the proportion of women with adequate test practice was $69.6 \%$, thus representing a coverage rate for the test that was slightly higher than that reported for women in Brazil as a whole $(66.0 \%)^{20}$ and for women in São José de Mipibu (64.4\%). ${ }^{19}$ Our rate was also very similar to those found in two studies conducted in Pelotas, Rio Grande do Sul, ${ }^{4,21}$ in which rates of $68.8 \%$ and $68.9 \%$, respectively, were reported. However, our rate was below the coverage rates reported for women in São Paulo $(77.3 \%)^{17}$ and São Leopoldo, Rio Grande do Sul (85.5\%). ${ }^{22}$ The adequacy of test practice demonstrated by our study participants was not influenced by the level of education. This is different from the results obtained in other studies conducted in this country, ${ }^{16,19,21}$ in which an association was found between the adequacy of this factor and the level of education.

Regarding knowledge, $36.7 \%$ of participants demonstrated adequate knowledge of the test, but our rate was lower than that of women in São José de Mipibu (46.1\%). ${ }^{19}$ We observed that adequate knowledge about the Pap test was found among higher proportions of women who were over the age of 20, ethnically white, married or living in a stable relationship with their partner, more highly educated and sexually active; and who possessed higher family income, and reported medical visits in the year preceding the survey and had children.

For women with a higher level of formal education and greater purchasing power, these results could be explained, at least in part, by the greater access to information about the health benefits of the test that these women had and, possibly, the greater opportunity for them to receive the test. However, the higher rates of adequate knowledge about the test observed among women who were sexually active, who visited a doctor more often and who had children may have been because they sought medical advice more often, either to obtain information regarding contraceptive methods or to receive prenatal care.

With regard to attitudes towards the test, $67.1 \%$ of the women interviewed had appropriate attitudes, such that they were able to mention the advantages and benefits of the procedure for their health and to correctly state the reason for periodically undergoing the test. This rate was similar to those reported for women in São José de Mipibu (63.3\%) ${ }^{19}$ and South Africa (60.6\%), ${ }^{23}$ but it was lower than the rate reported for Argentinean women $(80.5 \%)^{24}$ and higher than the rate observed for women in the Brazilian state of Rio Grande do Sul (45.6\%). ${ }^{25}$
Among the women who had an appropriate attitude towards the test, $46.7 \%$ considered it necessary to undergo the test periodically to prevent cervical cancer specifically, while $20.5 \%$ considered it necessary for preventing cancer, without specifying the type of cancer. A significant proportion of the women studied $(9.9 \%)$ considered the test necessary but did not know what the benefits of the test were for women's health. This finding suggests that when they learned about the test, the women participating in this study were not well informed regarding the importance of the procedure as a screening method for early diagnosis and treatment of lesions before those lesions progressed to a more malignant form of cancer. Better knowledge of this testing resource is essential for preventing cervical cancer.

The proportion of the women with an appropriate attitude towards the test was significantly higher among those who were already sexually active and married or living in a stable relationship, and among those who consulted a gynecologist during the year prior to the survey. The rates of appropriate attitudes increased proportionally with age, level of education and number of children. These findings were probably due to the greater degree of awareness that these women had about the advantages and benefits of periodic testing, in addition to the more readily available access to information and healthcare services that these women had. Other studies have also reported an association between appropriate attitudes and formal education. ${ }^{13,25}$ A study conducted in Campinas, ${ }^{16}$ for example, found an association between appropriate attitudes towards the test and formal education and family income.

In comparing our results regarding test practices with the results available in the literature, we saw that the rate of adequate test practice shown by the women in our study was similar to those described for women in Santo Angelo, Rio Grande do Sul ${ }^{25}$ and São José de Mipibu, ${ }^{19}$ but higher than the rates reported for women in South Africa ${ }^{23}$ and Argentina. ${ }^{24}$ The primary reasons given by women for not undergoing the test included absence of symptoms and being too embarrassed to undergo the test. These barriers were similar to those reported in other studies conducted in Brazil ${ }^{16,19,25}$ and Argentina. ${ }^{24}$

\section{CONCLUSION}

Clearly, health professionals including physicians and nurses play an important role in shaping the knowledge, attitudes and practices of women with regard to the Pap test. Success in this is reflected in the level of adherence to periodic testing among women and, consequently, the coverage rate for the test. Nevertheless, it appears that the forms of communication and/or methodology used by these professionals to inform women about the benefits and advantages of periodic testing may not be sufficiently clear or adequate. However, we cannot rule out the possibility that the time devoted to each consultation and the number of consultations received by 
these women may not have been sufficient to clarify all matters of concern, or that the women participating in this study had failed to make adequate use of the healthcare services provided. These potential problems require further attention from the municipality's healthcare managers, who need to commit to providing correct information about the test and its advantages and benefits for women's health, in order to improve adherence among the female population, thus meeting the coverage recommendations of the Brazilian Ministry of Health.

\section{REFERENCES}

1. International Agency for Research on Cancer. Centre International de Recherche sur le Cancer. Press release no 151. IARC confirms efficacy of cervix cancer screening for women 25-65 in reducing mortality. Available from: http://www.iarc.fr/en/media-centre/pr/2004/pr151. html. Accessed in 2013 (Mar 12).

2. Villa LL. Vaccines against papillomavirus infections and disease. Salud Publica Mex. 2003:45 Suppl 3:5443-8.

3. Instituto Nacional de Câncer José Alencar Gomes da Silva. Coordenação Geral de Ações Estratégicas. Coordenação de Prevenção e Vigilância. Estimativa 2012: incidência de câncer no Brasil. Rio de Janeiro: INCA; 2011. Available from: http://www. inca.gov.br/estimativa/2012/estimativa20122111.pdf. Accessed in 2013 (Mar 13).

4. Hackenhaar AA, Cesar JA, Domingues MR. Exame citopatológico de colo uterino em mulheres com idade entre 20 e 59 anos em Pelotas, RS: prevalência, foco e fatores associados à sua não realização [Pap smears of 20 - 59 year-old women in Pelotas, Southern Brazil: prevalence, approach and factors associated with not undergoing the test]. Rev Bras Epidemiol. 2006;9(1):103-11.

5. Entiauspe LG, Teixeira, LO, Mendoza-Sassi RA, et al. Papilomavírus humano: prevalência e genótipos encontrados em mulheres HIV positivas e negativas, em um centro de referência no extremo Sul do Brasil [Human papillomavirus: prevalence and genotypes found among HIV-positive and negative women at a reference center in the far south of Brazil]. Rev Soc Bras Med Trop. 2010;43(3):260-3.

6. Oliveira LHS, Ferreira MDPL, Augusto EF, et al. Genótipos de papilomavírus humanos em mulheres jovens assintomáticas de escolas públicas do Rio de Janeiro, Brasil [Human papillomavirus genotypes in asymptomatic young women from public schools in Rio de Janeiro, Brazil]. Rev Soc Bras Med Trop. 2010;43(1):4-8.

7. Muñoz M, Castellsagué X, de González AB, Gissmann L. Chapter 1: HPV in the etiology of human cancer. Vaccine. 2006;24 Suppl $3: 53 / 1-10$

8. Steenbergen RD, de Wilde J, Wilting SM, et al. HPV-mediated transformation of the anogenital tract. J Clin Virol. 2005;32 Suppl 1:S25-33.

9. Trottier H, Franco EL. The epidemiology of genital human papillomavirus infection. Vaccine. 2006;24 Suppl 1:S1-15.
10. Greenwood SA, Machado MFAS, Sampaio NMV. Motivos que levam mulheres a não retornarem para receber o resultado de exame Papanicolau [Motives which lead women not to return to receive the results of their pap smear test]. Rev Latinoam Enferm. 2006;14(4):503-9.

11. Bosch FX, Lorincz A, Muñoz N, Meijer CJ, Shah KV. The causal relation between human papillomavirus and cervical cancer. J Clin Pathol. 2002;55(4):244-65.

12. Villa LL. Prophylactic HPV vaccines: reducing the burden of HPVrelated diseases. Vaccine. 2006;24 Suppl 1:S23-8.

13. Martins LFL, Thuler LCS, Valente JG. Cobertura do exame de Papanicolaou no Brasil e seus fatores determinantes: uma revisão sistemática da literatura [Coverage of the Pap smear in Brazil and its determining factors: a systematic literature review]. Rev Bras Ginecol Obstet. 2005;27(8):485-92.

14. von Zuben MV, Derchain SF, Sarian LO, et al. The impact of a community intervention to improve cervical cancer screening uptake in the Amazon region of Brazil. Sao Paulo Med J. 2007;125(1):42-5.

15. Ramos AS, Palha PF, Costa Júnior ML, Sant'Anna SC, Lenza NFB. Perfil de mulheres de 40 a 49 anos cadastradas em um núcleo de saúde da família, quanto à realização do exame preventivo de Papanicolaou [Pap smear realization profile of women between 40 and 49 years registered at a family health center]. Rev Latinoam Enferm. 2006;14(2):170-4.

16. Amorim VM, Barros MB, César CL, Carandina L, Goldbaum M. Fatores associados à não realização do exame de Papanicolaou: um estudo de base populacional no Município de Campinas, São Paulo, Brasil [Factors associated with women's failure to submit to Pap smears: a population-based study in Campinas, São Paulo, Brazil]. Cad Saude Publica. 2006;22(11):2329-38.

17. Pinho AA, França-Júnior I. Prevenção do câncer de colo do útero: um modelo teórico para analisar o acesso e a utilização do teste de Papanicolaou [Cervical cancer prevention: a theoretical framework to analyze Papanicolaou test access and use]. Rev Bras Saúde Matern Infant. 2003;3(1):95-112.

18. Oliveira MMHN, Silva AAM, Brito LMO, Coimbra LC. Cobertura e fatores associados à não realização do exame de Papanicolaou em São Luis, Maranhão [Coverage and factors associated with not performing Pap smear screening tests in São Luís, Maranhão, Brazil]. Rev Bras Epidemiol. 2006;9(3):325-34.

19. Fernandes JV, Rodrigues SH, Costa YG, et al. Knowledge, attitudes, and practices related to Pap test by women, Northeastern Brazil. Rev Saude Publica. 2009;43(5):851-8.

20. Szwarcwald CL, Viacava F, Vasconcellos MTL, et al. Pesquisa Mundial de Saúde 2003: o Brasil em números. RADIS. 2004;23:14-33. Available from: http://www.ensp.fiocruz.br/radis/sites/default/files/radis_23. pdf. Accessed in 2013 (Mar 12).

21. Quadros CAT, Victora CG, Costa JSD. Coverage and focus of a cervical cancer prevention program in southern Brazil. Rev Panam Salud Publica. 2004;16(4):223-32. 
22. Muller DK, Dias-da-Costa JS, Luz AM, Olinto MT. Cobertura do exame citopatológico do colo do útero na cidade de São Leopoldo, Rio Grande do Sul, Brasil [Coverage of Pap smear tests in the city of São Leopoldo, Rio Grande do Sul State, Brazil]. Cad Saude Publica. 2008;24(11):2511-20.

23. Lartey M, Joubert G, Cronje HS. Knowledge, attitudes and practices of rural women in South Africa regarding the Pap smear. Int J Gynaecol Obstet. 2003;83(3):315-26.

24. Gamarra CJ, Paz EP, Griep RH. Conhecimentos, atitudes e prática do exame de Papanicolaou entre mulheres argentinas [Knowledge, attitudes and practice related to Papanicolaou smear test among Argentina's women]. Rev Saude Publica. 2005;39(2):270-6.

25. Racho D, Vargas VRA. Análise da prática e atitude sobre o exame preventivo de câncer de colo de útero em uma comunidade universitária [Analyses of practice and behaviors about the pap semear of feminine university population]. Rev Bras Anal Clin. 2007:39(4):259-63.

Acknowledgements: The authors would like to thank the Municipal Health Secretary of the municipality of Floriano for consenting to the study and, in particular, Dra. Maria do Socorro Freire de Sousa, General Coordinator of the Family Health Program, for her valuable assistance in providing relevant information for this study

Sources of funding: Financial support was provided by Conselho Nacional de Desenvolvimento Científico e Tecnológico - CNPq, Fundação de Amparo à Pesquisa do Estado do Piauí (FAPEPI; Projeto PPSUS EFP-2329/2009) and Universidade Federal do Piauí (UFPI)

\section{Conflict of interest: None}

Date of first Submission: July 3, 2012

Last received: December 21, 2012

Accepted: March 15, 2013

\section{Address for correspondence:}

Humberto Medeiros Barreto

BR 343, KM 3,5

Meladão - Floriano (PI)

CEP 64800-000

Tel. (+55 89) 3522-0136

Cel. (+ 55 89) 9928-2467

E-mail: hmbarreto@ufpi.edu.br 